\title{
4. Privacy and the global media in the information age
}

\section{ABSTIRACI}

The protection of privacy is being increasingly recognised worldwide by the courts, and media regulators, as a result of what is seen as a more powerful and intrusive media, and the effect of the internet. A right to privacy may even apply in a public place. This article examines the impact this has on the media in the information age? New Zealand now has a tort of interference with privacy. The criminal courts are also considering privacy values in issues ranging from suppression orders to release of court information to the public. The Broadcasting Standards Authority has revised its privacy principles. Codes of conduct with regard to the print media also acknowledge privacy. But the protection of privacy has its genesis in the 1890s and not in the digital age. A seminal article by Warren and Brandeis, 'The Right to Privacy' (1890), was a reaction to what was at that time seen as an over-powerful media. United States jurisprudence evolved to the Prosser and Keeton formulation in the 1960s. New Zealand jurisprudence has relied on this formulation to advance privacy rights. The English courts have taken a similar approach in the much publicised Douglas v Hello! and Naomi Campbell cases. The European courts, as a reaction to an overactive paparazzi, have pushed the bounds of privacy in the Peck and Princess Caroline cases. The High Court of Australia considered privacy in Lenah Game Meats Pty Ltd. Finally, the International Covenants and protection of privacy.

WILLIAM AKEL

Partner, Simpson Grierson, Auckland

\section{Introduction}

T TE ARE all conscious of the vital importance of freedom of expression, and of a free press as fundamental in any free and democratic society and all the more so in the digital age. The importance of freedom of expression is well established in our common law 
jurisprudence. John Stuart Mill (On Liberty, 1859) believed that freedom of expression was necessary in order to facilitate the discovery of the truth:

[T]he peculiar evil of silencing the expression of an opinion is, that it is robbing the human race; posterity as well as the existing generation; those who dissent from the opinion, still more than those who hold it. If the opinion is right, they are deprived of the opportunity of exchanging error for truth: if wrong, they lose, what is almost as great a benefit, the clearer perception and livelier impression of truth, produced by its collision with error. ${ }^{1}$

In Abrams v United States (1919)2, Justice O. W. Holmes, one of America's outstanding jurists, referred to the importance of freedom of expression in establishing a 'marketplace of ideas' from which truth could emerge:

The best test of the truth is the power of the thought to get itself accepted in the competition of the market.

In Judicial Remedies and the Constitution (1994) a prominent English jurist, Sir John Laws, argues that freedom of expression is an end in itself - an inalienable right:

Free speech is a corollary of the power of reason, of intellect, which is as natural in Man as the power of muscles and sinews, though altogether more important. And it is a necessary condition for the very exercise of reason that its possessor should have the faculty to communicate, since reason only has effect through language. Thus, free speech is a moral construct whose existence depends upon and is required by the fact that humanity is social, not solitary. It is not a means to an end, but an end in itself. Without it humanity is not humanity. It may therefore be described as an inalienable right (p. 226).

New Zealand has a Bill of Rights. Freedom of expression in our Bill of Rights is broad based.

Everyone has the right to freedom of expression, including the freedom to seek, receive, and impart information and opinions of any kind in any form. 
Pursuant to section 4 of the Bill of Rights, our courts are obliged to interpret and apply other legislation as consistently as possible with freedom of expression rights. And those rights may be subject only to such reasonable limits prescribed by law as can be demonstrably justified in a free and democratic society (section 5, Bill of Rights). The issue that needs to be considered is whether a right to privacy, or a right to be let alone, is a reasonable limitation on freedom of expression rights which is justified, in a free and democratic society.

We are all conscious of the claim that the media today is all powerful, all intrusive, and all ratings/commercially driven. This, it is said, is to the detriment of individual privacy and ultimately to the detriment of society as a whole. The claim is made that the search for the truth, and the public interest are no longer the imperatives of a free press. Whether these claims have any basis will depend on our own close experience of working in and with the media.

There must be a concern, however, that such a critical perception of the media will influence the courts and legislative bodies to reign in the media when it comes to issues of privacy, personal dignity and claims for personal autonomy and anonymity. Witness, for example, Justice Callinan of the High Court of Australia in ABC v Lenah Game Meats Pty Ltd (2001)

The means and sources of information (both legitimate and unlawful) available to the media are more numerous and diverse today than ever before: spy cameras, telephone interception devices, access to satellites, night vision equipment, thermal imaging, parabolic listening devices, telephoto lenses, and concealable video cameras to name only some. The means of instantaneous communication have been greatly enhanced in the last century. That taken with the great financial and other resources available to media organisations should, if anything, enable the margin for factual error to be much reduced. It should also be pointed out that photographs, and video films and other reproductions can be very valuable in the hands of many branches of the media, especially this syndicated media.

As populations expand, privacy becomes more elusive. The right to grant or refuse access to, and to allow to be published, accounts, or records, whether by way of film, sound recording, drawings, or otherwise, of what is occurring at a location at a particular time are 
rights for which very large sums of money can be demanded. These rights, however they might be described in proprietary terms, can be very valuable indeed. Some understanding of all of these matters is necessary for any discussion about, and a statement of the law with respect to, freedom of expression, privacy, new forms of property and defamation.

And:

Much news is in any event provided by overseas services and multinational companies. Wholesale comment, speculation, informed and uninformed, on the part of the authors of articles and daily newspapers seems to be encouraged. There are few articles today reporting what people have said that are free from the authors interpretation of, or, to adopt the parlance of the media, 'spin' on it. This may be a consequence of the fact that almost all reporters, even the most inexperienced, are given a by-line, a practice almost unknown a generation or so ago.

As stated whether or not we agree with Justice Callinan is a matter of individual experience. As Baroness Hale said in the Naomi Campbell (2002) ${ }^{4}$ case: 'One reason why press freedom is so important is that we need newspapers to sell in order to ensure that we still have newspapers at all.' The point however is that the desire to protect privacy, and to be left alone, is fundamental in both the civil and criminal context. But, freedom of expression is not itself some convenient byline to be eroded by a rush to privacy. What is crucial, and sometimes very difficult, is achieving in practice an acceptable balance between the competing interests in any given circumstances.

I will now review some of the broad and perhaps more high profile developments overseas and in New Zealand with regard to privacy law under the following headings.

- The genesis of privacy law in an article written by Warren and Brandeis in the United States in 1890; and the Prosser and Keeton formulation in 1960.

- Jacqueline Onassis, and adoptive parents in the United States.

- One photograph in Canada which made its way from Quebec to the Canadian Supreme Court.

- Venables, Michael Douglas and Catherine Zeta-Jones, and Naomi Campbell, in the United Kingdom. 
- Some CCTV footage in England that made its way to the European Court.

- Game meat in Tasmania - the High Court of Australia decision in Lenah Game Meats.

- The position in New Zealand and, in particular, the Court of Appeal landmark decision in Hosking $v$ Runting.

- The international covenants on privacy.

I stress I can only touch on some interesting cases simply to highlight the issues. We would need a few days to make it a comprehensive study. However, it can readily be seen that privacy values and interests have already impacted on the media, and will continue to impact upon freedom of expression rights, as the Legislature and Courts strive to seek a balance between freedom of expression in the information age, and the ability of individual citizens to personal autonomy, dignity and privacy. As one of the Law Lords in the House of Lords said in the Naomi Campbell case:

This case involves the familiar competition between freedom of expression and respect for an individual's privacy. Both are vitally important rights. Neither has precedence over the other. The importance of freedom of expression has been stressed often and eloquently, the importance of privacy less so. But it, too, lies at the heart of liberty in a modern state. A proper degree of privacy is essential for the well-being and development of an individual.

\section{The starting point: Warren and Brandeis}

The genesis of privacy law is the seminal article 'The Right to Privacy' (1890) 4 Harv. LR 94 by Warren and Brandeis, which was based principally on the proposition that an individual has a 'right to be let alone'. Even at that time, in the 1890 s, the authors believed that recent inventions such as instant photographs and the activities of newspapers were increasingly intrusive and a threat to a so-called right to be let alone. Warren and Brandeis observed:

The intensity and complexity of life, attendant upon advancing civilisation, have rendered necessary some retreat from the world, and man, under the refining influence of culture, has become more sensitive to publicity, so that solitude and privacy have become more essential to the individual; but modern enterprise and invention have, through invasions upon his privacy, subjected him to mental pain and distress, far greater than could be inflicted by mere bodily injury. 
This article was regarded as one of the most influential treatises in the law forming the basis of American jurisprudence on privacy. The article concluded that:

The protection afforded to thoughts, sentiments and emotions, expressed through the medium of writing or of the arts, so far as it consists of preventing publication, is merely an instance of the enforcement of the more general right of the individual to be let alone.

\section{Prosser and Keeton}

Although the United States courts acknowledged privacy values, particularly via the Fourth Amendment concerned with unlawful search and seizure, the major development in the civil jurisdiction on the tort of invasion of privacy was the Prosser and Keeton formulation. The basis for this formulation was an article by Dean William Prosser in 1960 (48 Californian LR 383). Prosser's article, like Warren and Brandeis, had a profound impact on privacy law in general. Prosser identified four privacy torts:

- Intrusion upon the plaintiff's seclusion or solitude, or into his private affairs.

- Public disclosure of embarrassing private facts about the plaintiff.

- Publicity which places the plaintiff in a false light in the public eye.

- Appropriation, for the defendant's advantage, of the plaintiff's name or likeness.

Looking at each of these in turn:

- The essence of the first tort is not publication, but intrusion, eg, interception of private discussions, peering into windows, harassing telephone calls.

- With the second tort, the protected interest is reputation. Prosser saw the tort as an extension of defamation areas not covered by defamation. It crucially eliminated the defence of truth.

- The third tort also protected reputation. The concern of course was that if taken to its extreme, the careful balance achieved in the law of defamation would be decimated. There was a risk that freedom of the press would simply disappear.

- The fourth tort is that of appropriation - the interest protected is a proprietary one. In today's world, pirating of a plaintiff's identity.

Prosser's four broad concepts have now been substantially incorporated as ss652A to 652E in the US Restatement of the Law, Second Torts. 


\section{The United States: Jacqueline Onassis and an adoption case}

With the Warren and Brandeis seminal article, and the Prosser and Keeton formulation, the origins of the tort of invasion of privacy are in the United States. The First Amendment's freedom of expression values remains paramount. The Fourth Amendment with regard to search and seizure, however, protects privacy. See for example:

- Olmstead v United States $(1928)^{5}$ - 'the right to be alone - the most comprehensive of rights, and the right most valued by civilised man'.

- $\quad$ Public Utilities Commission v Pollack (1952) - 'the right to be let alone is indeed the beginning of all freedom'.

Two cases of interest which recognised a right to privacy involved paparazzi harassment of Jacqueline Onassis Ronald E. Galella v Jacqueline Onassis (1982) ${ }^{7}$; and the right to keep private facts buried in the absence of any compelling reason for media publicity Hall v Post $(1987)^{8}$.

Having been constantly harassed by the paparazzi, Jackie Onassis obtained an order prohibiting Galella from harassing, alarming, blocking her path, touching her person, or coming within a certain distance of her, her children or her residence. The court held that the photographer deliberately and persistently violated the court order by actions and conduct offensive, menacing and contemptuous, and was held in contempt. The court considered other cases which addressed the issue of surreptitious news gatherers:

Under certain circumstances, surveillance may be so over zealous as to render it actionable ... it does not strain credulity or imagination to conceive of this systematic 'public' surveillance of another as being the implementation of a plan to intrude on the privacy of another.

The court concluded at p. 45:

Mrs Onassis is invested with a constitutional right to privacy-a right to be left alone. The right of privacy stands on high ground, cognate to the values and concerns protected by constitutional guarantees. Indeed, her 'right to be left alone' is exactly what Galella relentlessly and shockingly invaded...

In Hall v Post (1987) an adoptive mother and daughter brought an action 
against a newspaper and reporter alleging invasion of privacy by disclosure of private facts concerning an adoption which occurred 17 years prior to the article. The Court of Appeal of North Carolina held there was an invasion of privacy. It considered the difference between information to which the public was entitled to have, and morbid and sensational prying into private lives for its own sake. The court referred to the California Supreme Court in Briscoe v Readers Digest ${ }^{9}$ :

In a nation built upon the free dissemination of ideas, it is always difficult to declare that something may not be published. But the great general interest in an unfettered press may at times be outweighed by other great societal interests. As people we have come to recognise that one of these societal interests is that of protecting an individual's right to privacy. The right to know and the right not to have others not know are, simplistically considered, irreconcilable. But the rights guaranteed by the First Amendment do not require total abrogation of the right to privacy. The goals sought by each may be achieved with a minimum of intrusion upon the other.

The court continued:

In our view, there are private matters so intimate or personal that the obvious bounds of propriety and decency require their protection from public scrutiny in the absence of any compelling justification for their revelation.

The court said:

For the foregoing reasons, we conclude that in an appropriate case, an unwarranted and offensive publication of private facts which are not newsworthy may give rise to a claim for relief for tortuous invasion of privacy entitling the aggrieved party to at least nominal damages, and that plaintiffs have alleged sufficient facts to support this type of claim.

I now move north of the border to Canada. 


\section{Canada: The Supreme Court and one photograph from Quebec}

In Canada, the function of privacy has been equated with the fostering of personal autonomy and self development, essential for the well-being of the individual in society. It has also been described as at the heart of liberty in a modern state. The Supreme Court of Canada decision in Les Editions Vice-Versa Inc and Duclos v Aubry $(1998)^{10}$ is of importance. The case was an appeal from Quebec. It is based on the Quebec Charter which in turn reflects the long-standing acceptance in French law (which it has in common with German law) that privacy rights warrant broad legal protection (and thus may not be binding on the other Canadian provinces).

The claimant brought an action against a publisher for taking and publishing without her consent a photograph of her sitting in a public place. The court held that the taking of the photo, and the publishing of it, both constituted an invasion of the plaintiff's right to privacy. The court considered whether the right to one's image was a separate right of personality or an element of the right to privacy. In the court's view the right to one's image was an element of the right to privacy the claimant recovered damages.

\section{England: Venables, Douglas and Zeta-Jones, Naomi Campbell}

The English Court of Appeal and House of Lords have considered some high profile cases involving privacy. The English courts have been guided very much by Article 8 of the European Convention which protects 'private and family life', and the law of confidence as including privacy rights. In Venables v News Group (2001) ${ }^{11}$, the claimants, who were the young murderers of the toddler Jamie Bolger, sought to prevent newspapers from disclosing information about their new lives. The court held that the risk to the claimants' lives and their right to life required that the right to confidence protecting the disclosure of their new identities took precedence over the right of the media to free expression. In Douglas $v$ Hello! Ltd $(2001)^{12}$, the court held Michael Douglas and Catherine Zeta-Jones had an actionable right to privacy and damages over their wedding photographs. The court said the privacy right emanated from the common law action of breach of confidence, either independently or bolstered by the provisions of the Human Rights Act 1998. In Campbell v MGN Ltd (2004), supermodel Naomi Campbell successfully claimed damages for breach of privacy by the publication of articles and photos revealing that, contrary to her claims, she was a drug addict and was attending meetings for Narcotics Anonymous. 


\section{Europe: The European Court and some CCTV footage}

The decision of the European Court of Human Rights in Peck $v$ United Kingdom, $(2003)^{13}$ reflects the much stronger European tradition with regard to privacy rights. A reasonable expectation of privacy may arise notwithstanding the public locality in which the 'invasion' of privacy takes place.

The ECHR ruled that a British man's right to respect for his private life was violated when CCTV footage of him in a distraught state in a public place, a street, was released to the media. (The footage did not actually show an attempted suicide.) Peck was not aware that he had been filmed by a closedcircuit television camera installed by a local council. The council issued two photographs taken from the footage with an article entitled 'Defused-the partnership between CCTV and the police prevents a potentially dangerous situation'. Peck's face was identifiable. Two local newspapers published the photographs and it was also issued to Anglia TV (but with Peck's face being masked). The footage was also supplied to the BBC series Crime Beat. In trailers for the series, Peck's face was identifiable. The European Court upheld the complaint on the basis that a disclosure of the CCTV footage to the media constituted a 'disproportionate and unjustified interference with the applicant's private life' in violation of Article 8 of the European Convention of Human Rights. The court said that there was a zone of interaction of a person with others, even in a public context, which may fall within the scope of 'private life'.

\section{Australia: The High Court in Lenah Game Meats Ltd}

The Australian High Court considered invasion of privacy in Australian Broadcasting Corporation v Lenah Game Meats Pty Limited (2001). Lenah Game Meats applied for an injunction to stop the broadcast of covert filming carried out by ABC of Lenah's game works in Tasmania. The six judges of the High Court had different approaches, but Justices Gummow and Hayne (Caudron J concurring) considered:

The remaining categories, the disclosure of private facts and unreasonable intrusion upon seclusion, perhaps come closest to reflecting a concern for privacy as a legal principle drawn from the fundamental value of personal autonomy.

Justice Kirby recognised that the right of privacy is drawn from the fundamental value of personal autonomy. He considered that filmed 
images which are surreptitiously obtained are deemed to be confidential information, and that a person who comes into possession with knowledge of the confidential nature of such information, may come under a duty not to publish. As I referred to in the introduction, Callinan J was highly critical of the media in his dissenting judgment, and considered that the tort of invasion of privacy should apply in Australia.

Reference should also be made to a lower court decision in Queensland Grosse v Purvis (2003) ${ }^{14}$. A Queensland District Court judge became the first judge in Australia to find that people can sue for the tort of invasion of their privacy. Judge Skoien ordered the defendant to pay the plaintiff $\$ 178,000$ for the invasion of her privacy and other torts for a post traumatic stress disorder as a result of harassment and stalking.

\section{The New Zealand position}

There were a number of cases in New Zealand prior to Hosking $v$ Runting ${ }^{15}$ that recognised a privacy right, particularly where freedom of expression rights have been in issue in the criminal context. Two examples will suffice. In Police v O'Connor (1992) ${ }^{16}$, one of New Zealand's leading jurists, Justice Thomas, in a very full decision on the principle of open administration of justice, stated: 'Nor will the principle (of freedom of expression) invariably prevail against the citizen's right to privacy and the public interest in a law which protects privacy.' In Television New Zealand Ltd $v R(1996)^{17}$, our Court of Appeal was required to consider an application by the media to publish 'evidence' that had been ruled inadmissible in a murder trial. The accused (David Bain) had stood trial for the murder of his parents, brother and two sisters. In the course of the trial the defence had sought to adduce evidence of a hearsay nature in support of its contention that the father was the real killer (to hide an alleged incestuous relationship with one of the sisters who had been murdered). Relying on the twin principles of freedom of expression and open administration of justice, the Court of Appeal ruled that the inadmissible evidence should be made available to the media. On the issue of privacy, the court stated:

[The immediate family of the deceased] concern about the prospect of further wounding disclosures affecting their family dignity and privacy was communicated to us by the Crown.

We were referred to a helpful elaboration of the concept of privacy prepared by the Broadcasting Standards Authority ... The first of its 
principles is that the protection of privacy includes legal protection against the public disclosure of private facts where the facts disclosed are highly offensive and objectionable to a reasonable person of ordinary sensibilities.

There can be no doubt that the alleged facts in issue in the present application do fall within the last part of that statement. But the criminal justice system itself requires that some highly offensive facts, once private, do become public. That happens, as in this case, in accordance with the tenets of public justice in the fair hearing of the cases presented by the prosecution and the defence.

In 2003 the Court of Appeal heard the Hosking $v$ Runting case, giving its decision in March 2004. Mike Hosking, a media personality, and his wife brought an action on behalf of their small daughters to stop Pacific Magazines Ltd publishing photos of Mrs Marie Hosking and the children that had been taken by professional photographer Simon Runting in Broadway, Newmarket. The High Court found that the law in New Zealand did not recognise a tort of invasion of privacy. Three judges in the Court of Appeal, however, considered that there should be such a tort. The other two judges thought otherwise.

In the leading judgment, Justices Gault and Blanchard said that there were two fundamental requirements for a successful claim for interference with privacy:

- The existence of facts in respect of which there is a reasonable expectation of privacy; and

- Publicity given to those private facts that would be considered highly offensive to an objective reasonable person.

These two judges said no court can prescribe all the boundaries of a cause of action in a single decision and that the claim will evolve through future decisions as courts assess the nature and impact of particular circumstances. They emphasised however that they are concerned only with wrongful publicity given to private lives. They are not concerned at this time with unreasonable intrusion into a person's solitude or seclusion. In many instances this aspect of privacy will be protected by the torts of nuisance, or trespass, or by laws against harassment, but this may not always be the case. Justices Gault and Blanchard said that private facts are those that may be known to 
some people, but not to the world at large. There is no simple test for what constitutes a private fact. They further say that the right to privacy is not automatically lost when a person is a public figure, but his or her reasonable expectation of privacy in relation to many areas of life will be correspondingly reduced as public status increases. Involuntary public figures may also experience a lessening of expectations of privacy, but not ordinarily to the extent of those who willingly put themselves in the spotlight. They say the special position of children must not be lost sight of.

The concern of the law so far as these two judges are concerned is with widespread publicity of very personal and private matters. Similarly publicity, even extensive publicity of matters which, although private, are not really sensitive should not give rise to legal liability. The concern is with publicity that is truly humiliating and distressful or otherwise harmful to the individual concerned.

Most importantly there should be available in cases of interference with privacy a defence enabling publication to be justified by a legitimate public concern in the information, but not where it is merely interesting to the public. In summary, as these two judges saw it, the reasons for recognising a tort of invasion of privacy were as follows; it is consistent with our obligations under the International Covenant on Civil and Political Rights; it is a development that the Law Commission has recognised; it reflects the experience of the Broadcasting Standards Authority and similar British tribunals; it enables competing values to be reconciled; and it is the same as what has taken place in the United Kingdom under the breach of confidence claims.

Justice Tipping also held that a tort of invasion of privacy exists. To him the first and fundamental ingredient of the tort should be that the plaintiff must be able to show a reasonable expectation of privacy in respect of the information or material which the defendant has published or wishes to publish. The necessary expectation can arise from the nature of the information or material or the circumstances in which the defendant came into possession of it or both. In most cases that expectation is unlikely to arise unless publication would cause a high or substantial level of offence. It should be a defence to an action for invasion of privacy that the information or material published about the plaintiff's private life is a matter of legitimate public concern.

The two dissenting judges took the view that the tort was an unjustified limit on the right to freedom of expression as per section 14 of the $\mathrm{New}$ Zealand Bill of Rights Act. 
The New Zealand courts have not been shy when extending the reach of privacy law even prior to Hosking. A lower court decision in $2002^{18}$ was over photos taken by a defendant of the claimant when she was working as a prostitute. The photographs focused on her private parts. Identification was extremely unlikely. The court found that there was a breach of privacy when the photographs were sent to a magazine. There was absolutely no public interest in the publication of the photographs, and given the claimant's lack of consent, the defendant was liable for invasion of privacy.

In Bradley $v$ Wingnut Films (1993) ${ }^{19}$, Wingnut, (an early Peter Jackson company) produced a 'splatter' film, Brain Dead, which included film shot in a cemetery. The claimant was a holder of an exclusive right to a burial plot. The tombstone marking the claimant's burial plot appeared in the film as a backdrop, albeit briefly. Nothing on it could be read. Claims were made of intentional and fiction of emotional harm, breach of privacy, defamation, malicious falsehood, trespass and negligence. The court was prepared to accept that a tort of privacy formed part of New Zealand law relying very much on the Prosser formulation. However in that case the claimant could not meet the requirement that the facts be 'private facts'. The tombstone, after all, was in a public cemetery.

In $P v D(2000)^{20}$, the High Court held that publication by the media of information that a public figure had been treated in a psychiatric hospital was a breach of privacy because the information was a private fact; the intended publication was a public disclosure; and disclosure would be highly offensive and objectionable to a person of ordinary sensibilities in the claimant's position. Again the Prosser and Keeton formulation was applied.

Privacy features elsewhere in the law in New Zealand. Pursuant to section 4(1)(c) of the Broadcasting Act every broadcaster is responsible for maintaining in their programmes, and their presentations, standards which are consistent with 'the privacy of the individual'. There are seven Broadcasting Standards Authority privacy guidelines which are similar to the Prosser and Keeton formulation. One of the privacy principles provides that the protection of privacy also protects against public disclosure of some kinds of public facts. The public facts contemplated concern events (such as criminal behaviour) which have, in effect, become private again, for example through the passage of time. Nevertheless the public disclosure of private facts will have to be highly offensive to a reasonable person. 
The BSA Privacy Guidelines were referred to in Hosking. In TV3 Network Services v Broadcasting Standards Authority $(1995)^{21}$, Chief Justice Eichelbaum agreed with the BSA that the broadcast of the fact that the complainant had been the victim of incest as had been her daughters was highly offensive and objectionable. It was thus in breach of the Privacy Principles. There are many BSA decisions on privacy issues including door stepping, electronic eavesdropping, personal abuse, privacy of rape victims, filming at funerals and personal distress, suppression orders and so on.

As already referred to, privacy values underline much of the criminal process, for example:

- Suppression orders.

- Victims of sexual offences have always been entitled to privacy in the Court process.

- The Victims' Rights Act 2002-section 7 specifically refers to respect for the victim's dignity and privacy, and section 16 provides a presumption against the giving of a victim's address in evidence. The overall emphasis in the Act is on the privacy of victims.

- The Law Commission Report 'Delivering Justice for All' (March $2004)^{22}$ wishes to give more emphasis to privacy in the court process. The president of the Law Commission, Sir Geoffrey Palmer, in 2006 announced a major review of privacy law in New Zealand.

- Inspection of court files. In $R v$ Mahanga (2001) ${ }^{23}$ and Mafart $v$ TVNZ (2006) ${ }^{24}$, the Court of Appeal and Supreme Court have said that once a criminal trial has concluded there is more room to recognise individual privacy interest. Protection of individual privacy of an accused was a legitimate factor to take into account in deciding whether the media were entitled to inspect the court records of a particular case.

- The Noel Rogers $v$ TVNZ (2006) case brings into sharp focus the impact of the developing tort of invasion of privacy, on the open justice system. The issue in that case is whether TVNZ should be injuncted from broadcasting a police videotaped confession that the Court of Appeal ruled inadmissable at Rogers' trial on the basis that it had been obtained in fundamental breach of his rights. After a five-week trial, a jury acquitted Rogers of a charge of murder. The 
full Court of Appeal allowed TVNZ's appeal after weighing the privacy interests of Rogers and the principle of open administration of justice, in particular as it relates to the court inadmissibility ruling. Rogers then appealed to the Supreme Court. The appeal was heard on 14 December 2006. The Supreme Court's decision is awaited with interest.

- Reference should also be made to privacy and data protection in the Privacy Act 1993, although there is an exemption for the media in news and current affairs.

\section{The International Covenants}

While the International Covenants protect freedom of expression, they also provide for privacy rights. Article 12 of the Universal Declaration of Human Rights:

No one shall be subjected to arbitrary interference with his privacy, family, home or correspondence ... Everyone has the right to the protection of the law against such interference or attacks.

Article 17 of the International Covenant on Civil and Political Rights:

No one shall be subjected to arbitrary or unlawful interference with his privacy, family, home or correspondence, nor to unlawful attacks on his honour and reputation.

And as mentioned in Article 8 of the European Convention on Human Rights:

Everyone has the right to respect for his private and family life, his home and his correspondence.

\section{Conclusion}

Privacy issues arise in many different areas of the law. Two recent examples of this are the US Supreme Court decisions in 2005 in Lawrence $v$ Texas $^{25}$ and US v American Librarian Association Inc. 26 In the first, the court struck down Texas legislation prohibiting two consenting adults engaging in sexual practices common to a homosexual lifestyle. The second, struck down children's internet protection legislation. The majority of the Supreme Court 
was prepared to accept that close monitoring of computer users would be more intrusive than the use of filtering software and would turn librarians into compliance officers.

In this respect, I have not ventured into the world of internet privacy, and such issues as tracking and sniffing, cookies and web bugs, scrapping, interception and monitoring of emails, spam, and email harvesting and the like. There are some important cases in this area. The main concern, of course, is that few internet users really understand the use to which these devices are put and how they impact upon privacy. The media could well explore this area.

I have also not referred to the important issue of workplace privacy. Again, privacy and confidentiality arise in such broad areas as evaluative material, surveillance cameras, random drug testing and the like. Again a fruitful area for the media. Nor for that matter have I considered self-regulation by the media through international and national codes of ethics and national press complaints commissions.

However, I hope that the cases that I have referred to will highlight what I believe to be one of the most important issues facing the media today as we become a truly global village in the information age - that is balancing freedom of expression with privacy values and interests.

\section{References}

1. On Liberty. The Liberal Arts Press (1956), p. 21.

2. 250 US 616 p. 630

3. Australian Broadcasting Corporation v Lenah Game Meats Pty Ltd (2001) 208 CLR 199

4. Campbell v MGM Ltd [2004] 2 WLR 1232

5. 277 US 438 (1928)

6. 342 US 451 (1952)

7. 533 F. Supp.1076; 1982 US Dist. Lexis in 11614; 8 Media L. Rep. 1321

8. (1987) 355 SE 2nd 819

9. $483 \mathrm{p} \mathrm{2d} \mathrm{34;} 57$ ALR 3d 1 (1971)

10. (1998) 50 CRR (2d) 225

11. [2001] 1 All ER 908

12. [2005] 4 All ER 128

13. [2003] ECHR $44647 / 98$

14. (2003) Aust Torts Reports 81-706

15. [2005] 1 NZLR 1

16. [1992] 1 NZLR 87

17. [1996] 3 NZLR 393 
18. L v G [2002] DCR 234

19. [1993] 1 NZLR 415

20. [2000] 2 NZLR 591

21. [1995] 2 NZLR 720

22. Law Commission Report NZLRCR 85, 2004 Delivering justice for all—a vision for New Zealand courts and tribunals

23. [2001] 1 NZLR 641

24. [2006] 3 NZLR 18

25. 539 US 558; 123 S Ct 2472 (2003)

26. 539 US 194 (2003)

William Arkel is a senior litigation and dispute resolution partner with Simpson Grierson and is one of New Zealand's foremost defamation and media lawyers. He has also acted in many cases in the South Pacific-particularly in the Cook Islands and Samoa. This article was presented as a keynote paper at the Second Joint Journalism Education (JEA)/Journalism Education Association of New Zealand (JEANZ) conference, Auckland, December 4-7. William.Akel@simpsongrierson.com 